\title{
Sclerotinia rot of rapeseed mustard: A comprehensive review
}

\author{
Rakesh $^{1 *}$, A. S. Rathi ${ }^{1}$, Pawan Kumar ${ }^{2}$, Anil Kumar ${ }^{1}$ and Pavitra Kumari ${ }^{1}$ \\ ${ }^{1}$ Department of Plant Pathology, CCS Haryana Agricultural University, Hisar-125004 (Haryana), INDIA \\ ${ }^{2}$ Krishi Vigyan Kendra, Jalandhar -144039 (Punjab), INDIA \\ ${ }^{*}$ Corresponding author. E-mail: punia.rakesh98@gmail.com
}

Received: January 27, 2016; Revised received: August 8, 2016; Accepted: November 20, 2016

\begin{abstract}
Indian mustard [Brassica juncea (L.) Czern \& Coss.] is one of the major oilseed crops cultivated in India and around the world. It is extensively grown traditionally as a pure crop as well as intercrop (mixed crop) in marginal and sub-marginal soils in the eastern, northern and north western states of India. Cool and moist climate of winter months is the major factor for luxuriant growth and productivity of mustard in these states. Despite considerable increase in productivity and production, a wide gap exists between yield potential and yield realized at farmer's field, which is largely due to biotic and abiotic stresses. The destructive diseases of rapeseed-mustard include those caused by fungi, bacteria, viruses and phytoplasma. Among them, Sclerotinia stem rot is the most serious fungal disease that causes maximum damage in Indian mustard. This paper reviews the research and development of Sclerotinia rot in rapeseed-mustard during the past years in relation to pathogen taxonomy, biology, epidemiology, disease cycle and management. The paper also attempts to present future outlook and strategy for Sclerotinia rot of rapeseed mustard research.
\end{abstract}

Keywords: Management, Rapeseed-mustard, Sclerotinia rot, Survival

\section{INTRODUCTION}

Rapeseed-mustard is the third most important oilseed commodity in the world after soybean (Glycine max) and palm (Elaeis guineensis Jacq) in world agriculture and India is the third largestproducer with global contribution of 28.3 per cent acreage and 19.8 per cent production (Shekhawat et al., 2012; Bandopadhyay et al., 2013). In India, rapeseed-mustard crops are cultivated on an area of 6.45 million ha with a production of 7.28 million tones and with an average yield of $1128 \mathrm{~kg} / \mathrm{ha}$ (Anonymous, 2015). Among the oilseed brassicas, mustard (Brassica juncea), yellow sarson ( $B$. campestris var. yellow sarson), brown sarson ( $B$. campestris var. brown sarson), toria (B. campestris var. toria), oilseed rape (B. napus) and Karan rai ( $B$. carinata) are grown for edible oil, whereas black mustard (B. nigra) is used as a condiment and for pickle making. The leaves of young plants are used in the human diet as a green vegetable. The oilseed brassicas usually contain 38-57 per cent of erucic acid, 4.7-13 per cent of linolenic acid and 27 per cent of oleic acid and linoleic acids, which are of high nutritive value required for human health (Kumar et al., 2014). Rapeseed- mustard [Brassica juncea (L.) Czern \& Coss.] is one of the most important oilseed crops, are exposed to various pathogen, which infect and disturb the normal physiological functions during growth and development. Among the diseases that hampered the productivity of oilseed brassicas, Sclerotinia rot caused by Sclerotinia sclerotiorum (Lib.) de Bary is most predict- able diseases worldwide. In the changing climate, diseases in mustard have been recognized as a major threat in causing more economic losses these years than before. Because, some of the diseases known as serious in past have become more or less serious depending upon the geographical locations in the country and some of the minor disease problems have now become major ones. In India, the Sclerotinia stem rot was considered as minor importance few decades ago but recently this disease is a serious handicap in successful cultivation of rapeseed-mustard (Rakesh, 2014).

\section{DISTRIBUTION AND HOST RANGE}

S. sclerotiorum causing Sclerotinia stem rot or white stem rot in rapeseed-mustard is worldwide in distribution and is pathogenic to more than 400 plant species (Purdy, 1979; Boland and Hall, 1994) and more than 500 plant species (Sharma et al., 2015) at various developmental stages of plants. The pathogen poses a hazard to many dicotyledonous crops such as rapeseed -mustard, sunflower, soybean, edible dry bean, chickpea, peanut, dry pea, lentils and various vegetables, even also reported to infect monocotyledonous species such as onion, tulip and many others (Boland and Hall, 1994; Bolton et al., 2006).

\section{HISTORY OF PATHOGEN SCLEROTINIA SCLEROTIORUM}

S. sclerotiorum was first described in 1837 by Libert as Peziza sclerotiorum and later named as $S$. libertiana 
Fuckel in 1870 (Purdy, 1979). This binomial was accepted until it was demonstrated as incoherent with the International Rules of Botanical Nomenclature, so the name $S$. libertiana was changed to $S$. sclerotiorum (Lib.) Massee (Wakefield, 1924). However, Wakefield (1924) incorrectly reported that the combination of $S$. sclerotiorum was first used by G.E. Massee in 1895 , resulting in the citation $S$. sclerotiorum (Lib.) Massee. However, it was later found that de Bary had used this Latin name earlier, so the proper name was established as S. sclerotiorum (Lib.) de Bary (Purdy, 1979). The early taxonomy of the three species (sclerotiorum, minor and trifoliorum) was based on the size and general characteristics of the sclerotium, host range and dimensions of ascospores and asci (Willetts and Wong, 1980). However, several studies (Purdy, 1955; Price and Colhoun, 1975; Grogan, 1979) showed that this system was inadequate and a number of species, originally thought to be unique, were actually all members of the $S$. sclerotiorum species. S. sclerotiorum belonged to the Sclerotiniaceae Whetzel, a family of the class Ascomycotina. The pathogen belongs to kingdom-Fungi, phylumAscomycota, class-Discomycetes, order-Helotiales, family-Sclerotiniaceae and genus-Sclerotinia. Hyphae of Sclerotinia are hyaline, septate, branched and multinucleate; mycelium may appear white to tan and no asexual conidia are produced, however, numerous black coloured sclerotia are formed in the culture (Bolton et al., 2006).

\section{YIELD LOSSES}

Sclerotinia rot occurs every year in all the rapeseedmustard growing areas of the world. Yield loss estimates due to Sclerotinia disease have been made as high as 28 per cent in individual rapeseed fields in Alberta and 11.1 to 14.9 per cent in Saskatchewan, Canada (Morrall et al., 1976). This disease caused severe yield losses up to 50 per cent in winter oil seeds in Germany (Horning, 1983). At the time of harvesting and threshing, sclerotia of this fungus got mixed with seed and this represented an objectionable seed contaminant for export from one country to another and thus affected the marketability of the crop. The quality of seed even in partially infected plants has been adversely affected (Kruger et al., 1981). In Nepal, grain yield, plant height, number of siliquae per plant and 1000 grain weight were found reduced due to stem rot incidence and yield loss attributed to 75 per cent (Chaudhary, 1993). Infestation level of 40 per cent may cause yield losses up to 50 per cent in oilseed rape, as a result of a reduced thousand seed weight or an early shattering of pods (Pope et al., 1989). The pathogen has been reported to be endemic in North Dakota, with an annual average incidence of 13.6 per cent and had direct economic impact estimated as US 94 million for the period from 1991 to 2002 (Lamey, 2003). Del Rio et al. (2007) 国 reported disease incidence from 1 to 59 per cent in North Dakota and observed that for every per cent of Sclerotinia rot incidence, yield reduced by an average of
$13.1 \mathrm{~kg} / \mathrm{ha}$, i.e., 0.52 per cent of potential yield. Rape (B. napus) yield has also been observed decline in southern Australia from 0.39 to $1.54 \mathrm{t} / \mathrm{ha}$ due to Sclerotinia stem rot (Kirkegaard et al., 2006). In India, Shaw and Ajrekar (1915) were first to report S. sclerotiorum on several hosts including rapeseed-mustard causing Sclerotinia rot. The disease has assumed a serious proportion in mustard growing areas in India (Lodha et al., 1992; Krishnia et al., 2000) as the incidence of this disease was noticed up to 72 per cent in Rajasthan (Shivpuri et al., 2000; Ghosolia et al., 2004) and up to 80 per cent in Punjab and Haryana (Kang and Chahal, 2000). Sharma et al. (2001) also observed up to 49.2 per cent disease incidence from Haryana, however, in few areas the disease incidence has approached up to 80 per cent. Losses in yield up to 72 per cent from Uttar Pradesh and up to 50.9 per cent from Rajasthan in mustard due to this disease have been also reported (Chauhan et al., 1992; Singh, 1998). Plants infected at or before flower initiation resulted in 100 per cent yield loss, whereas, infection after flowering stage caused more than 50 per cent yield loss (Shukla, 2005).

\section{DISEASE SYMPTOM}

S. sclerotiorum causes more or less similar symptoms on leaves, stem and siliquae as fluffy white mycelia and sclerotia are produced after mycelial growth (Fig. 1.) when the nutrition is not sufficient or other conditions are favourable for sclerotial development (Christias and Lockwood, 1973). Sclerotinia stem rot in rapeseed mustard starts as elongated, water soaked lesions on stem especially at base or at internodes and later white mycelial growth covers these lesions and affected plants look whitish from distance. The disease becomes air borne and spread through infected flower petals which fall and become lodged between the main stem and side branches. Large oval to round shaped holes are also formed on leaves due to air borne infection. Under severe infection, defoliation, shredding of stem, wilting and drying of plants occurs. Infected plants will ripe earlier and stand out among green plants (Meena et al., 2014).

\section{ENZYME OF SCLEROTINIA SCLROTIORUM}

The explosive pathogenicity of $S$. sclerotiorum under favourable conditions and the ability of its sclerotia to withstand adverse conditions allow it to be a flourishing pathogen. Peroxidase and phenylalanine ammonialyase (PAL) are two enzymes frequently associated with infection by phytopathogens (Hammerschmidt et al., 1982; Shirasshi et al., 1989; Southerton and Deverall, 1990). The stimulation of the activities of these enzymes has been correlated with resistance to infection in many of the available reports, but conclusive evidence of their role in the defense mechanism of plants is not yet available. The biochemical processes involved in the expression of resistance in B. napus are rarely known. However, the accumulation of a phy- 

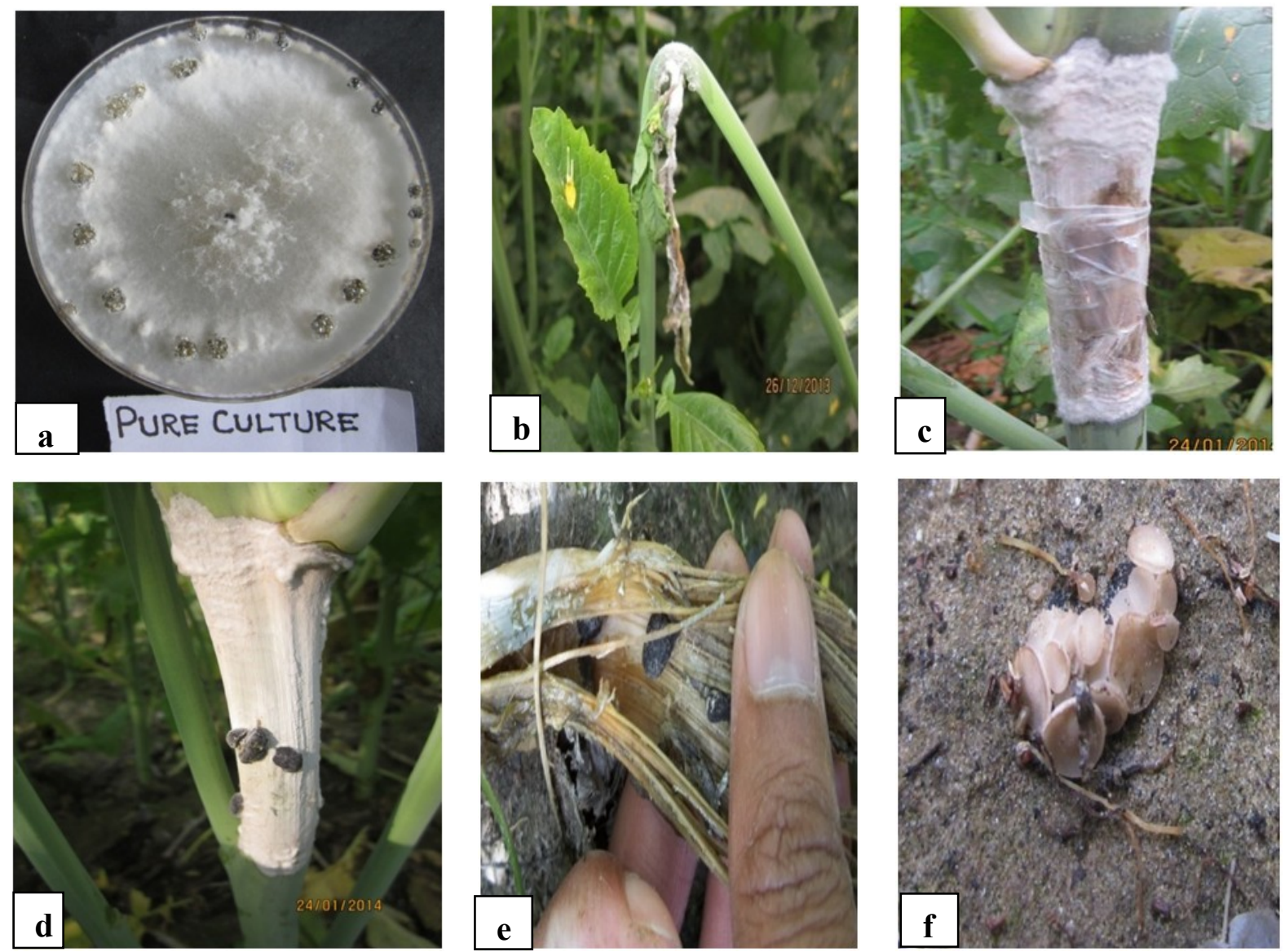

Fig. 1. a: Pure culture of Sclerotinia sclerotiorum in Petri dish, $\boldsymbol{b}$ and $\boldsymbol{c}$ : cottony white mycelium on infected plant stem, d: formation of sclerotia on the stem, $\boldsymbol{e}$ : Sclerotia inside the infected pith of stem, $\boldsymbol{f}$ : production of apothecia from the sclerotia.

toalexin in Brassica sp. in relation to a hypersensitive reaction toward L. maculans has been reported (Rouxel et al., 1989). S. sclerotiorum is known to produce pectinolytic and cellulolytic enzymes (Lumdsen, 1969; Favaron et al.,1988; Marciano et al., 1982). The level of these enzyme activities correlates with the development of disease symptoms (Favaron et al., 1988; Lumdsen, 1976).

\section{BIOLOGY AND DISEASE CYCLE OF SCLE- ROTINIA SCLEROTIORUM}

S. sclerotiorum (Lib.) de Bary is necrotrophic fungal pathogen in the Ascomycota and Order Helotiales produce fluffy white mycelium on and in infected plant parts. This mycelium aggregates itself into sclerotia, which are the structures that allow Sclerotinia species to survive in soil in the absence of plant host. A sclerotium is a hyphal aggregate with an outer black rind, several cells thick containing melanin, a compound that is believed to play an important role in protection from adverse conditions and microbial degradation in many fungi (Bell and Wheeler, 1986; Henson et al., 1999). Sclerotia buried in the plough layer of soil can survive and remain infective for up to 5 years and there are four stages in its life cycle: sclerotium, apothecium, ascospore, and mycelium (Hieu, 2007). Germination of fungal sclerotia has been reported to be of two types i.e. myceliogenic and carpogenic (Coley-Smith and Cooke, 1971). In myceliogenic germination, the sclerotium produces mycelium when soil remains wet and cool and the optimal conditions for germination are near-saturated wetness with soil temperatures of 12 to $24^{\circ} \mathrm{C}$. These conditions are created by extended rainy periods, or by irrigation in combination with soil shading due to closure of the crop canopy. These hyphae infect roots and crowns and other plant parts that are touching the ground. Infection then spreads to aboveground plant parts (Coley-Smith and Cooke, 1971). Sclerotia of $S$. sclerotiorum most commonly produce a mushroom-like fruiting body termed as apothecium and carpogenic germination of apothecium usually requires the sclerotia to be in wet soil for one to two weeks prior to germination. At soil depths of up to 2 $\mathrm{cm}$, apothecia can extend from the sclerotia to reach the soil surface. One or several apothecia can emerge from a single sclerotium. Apothecia are fleshy-colored discs measuring 4 to $8 \mathrm{~mm}$ in diameter. They produce ascospores as a result of a sexual process (Coley-Smith and Cooke, 1971). Ascospores release and petal fall should occur at the same time (Kruger, 1980). Morrall 
and Dueck $(1982,1983)$ have reported severe infections in the fields with few or no apothecia. Clarkson et al., (2003) reported that apothecia of S. sclerotiorum were produced at an optimum temperature of $15^{\circ} \mathrm{C}$ and ascospores survived a wide range of conditions, but high temperature and humidity reduced the viability and no apothecial initials were produced at either $30^{\circ} \mathrm{C}$ or $5^{\circ} \mathrm{C}$; continuous leaf wetness of $48-72 \mathrm{~h}$ were required for infection by ascospores. The infection by $S$. sclerotiorum in yellow sarson and $B$. compestris var. toria was aggravated by low temperature, heavy rain fall and closer spacing (Sexsena and Rai, 1987). The requirement of moisture for carpogenic germination and growth of the pathogen were the reasons why rainy periods or irrigation are coupled with outbreaks of disease on certain crops.

\section{SURVIVAL/ VIABILITY OF SCLEROTIA OF SCLEROTINIA SCLEROTIORUM}

S. sclerotiorum (Lib.) de Bary is a facultative parasitic Ascomycete fungus (Kirk et al., 2001), and can grow well even in an unfavourable environment and survive for up to 8 years in soil in the sclerotia form (Adams and Ayers, 1979). Holley and Nelson (1983) reported that when the inoculum density increased up to a certain level, after that there was not much effect on the disease incidence. The disease incidence increased with increase in the density of inoculums and decreased with increase in the age of inoculums. The average disease incidence with inoculums of different ages varied from 48.5-74.7 per cent with different loads of inoculums (Ghasolia and Shivpuri, 2009). Survival of fungal sclerotia has been reported to be of two types i.e. myceliogenic and carpogenic (ColeySmith and Cooke, 1971). Crisan and Urlea (1979) reported that 3-12 apothecia per sclerotium could be produced distally under controlled conditions, while Kapoor et al. (1987) observed 7-9 apothecia per stripe with 3-21 stripes per activated sclerotia. Susan et al. (1990) recorded that the more apothecia were produced from sclerotia placed at $0-2 \mathrm{~cm}$ than from those buried deeper. Low pre-conditioning temperature and continuously high moisture are crucial for carpogenic germination (Huang and Kozub, 1991; Dillard et al., 1995; Harvey et al., 1994). Moreover, the percentage of apothecia producing sclerotia decreased significantly with increasing depth of burial in the soil (BenYephet, 1993). Numerous apothecia developed after one month of placement from field collected sclerotia buried at $1 \mathrm{~cm}$ followed by $2 \mathrm{~cm}$ depth (Singh and Singh, 1988). No apothecia emerged from pseudosclerotia buried at depths of greater than or equal to $3 \mathrm{~cm}$, and the critical depth of burial was determined at $2.6 \mathrm{~cm}$ (Ngugi, et al., 2002). Ghasolia et al. (2005) reported that production of apothecia was higher when sclerotia were placed at soil surface (0 $\mathrm{cm})$ and decreased significantly with the increasing depth of burial. Amongst different soil types, the least number of apothecia production was recorded in sandy soil whereas, sandy loam soil resulted in maximum number of apothecia production (Mehta et al., 2009). Sclerotia, the resting structures which allow pathogen to survive for long periods of time under adverse conditions, are formed in the soil and in the stems of the infected tillers at the end of the season. As early as Dillion-Weston et al. (1946) estimated that sclerotia of $S$. trifoliorum causing disease in clover survived for 6-8 years in field and these sclerotia required prolong period of moist soil to germinate myceliogenically and/or carpogenically. These sclerotia play a major role in disease cycles as they produce inoculum and are the primary long-term survival structures (Adams and Ayers, 1979; Willetts and Wong, 1980). Few studies have also quantified the sclerotial survival of Sclerotinia species at different depths and duration in soil (Pande et al., 2008; Cosic et al., 2014). The viability of sclerotia on the surface declined rapidly due to the alternate wetting and drying of soil (Maiti and Sen, 1988). Survival was significantly influenced by depth of burial and by sclerotial treatment before burial. About 11-31 per cent of the sclerotia buried deeper than $2.5 \mathrm{~cm}$ survived after 30 days, whereas 65-84 per cent of those on the soil surface remained viable (Smith et al., 1989). Significant reductions in the mean number of sclerotia and lettuce drop incidence occurred on the crop immediately after deep ploughing (Subbarao et al., 1996). The effect of tillage on survival of sclerotia is poorly studied and no generalizations can be made to aid in management of the pathogen. There is evidence that leaving the sclerotia on the soil surface enhances degradation, whereas burying the sclerotia enhances survival. It is thought that the more dramatic changes in temperature and moisture on the soil surface are deleterious to sclerotia (Rakesh et al., 2015). Gurjar et al. (2004) stated that viability of sclerotia of Sclerotium rolfsii in chilli plant was reduced when buried in soil beyond $4 \mathrm{~cm}$ depth and lost their viability completely beyond $14 \mathrm{~cm}$ depth after 19 months. Sclerotia on the soil surface had the highest viability $(57.5 \%)$ followed by those at $5 \mathrm{~cm}$ depth $(12.5 \%)$ and only 2.5 per cent of those placed at the $10 \mathrm{~cm}$ depth after twelve months (Duncan et al., 2006). Gradual reduction in viability of sclerotia (germination percentage) of S. sclerotiorum, was observed with the increase in soil depth and duration of burial both under screen house and field conditions (Rakesh et al., 2015).

\section{MEASUREMENT OF THE DISEASE SEVERITY}

An appropriate method of disease assessment is a prerequisite for the identification of resistance to Sclerotinia rot in rapeseed mustard. The appearance of dis- 
ease is initially observed both on leaves and stem later on sclerotia formation on the stem and inside the infected piths of stem, which is responsible for yield losses (Meena et al., 2014). A key for the assessment of Sclerotinia rot, disease rating was recorded according to 0-4 scale of Lesovoi et al. (1987) with slight modification to assess disease severity $[0=$ no visible lesion on stem; $1=1 / 4$ stem girdled by lesion; $2=1 / 2$ stem girdled by lesion; $3=3 / 4$ stem girdled; $4=$ more than $3 / 4$ stem girdled] and per cent disease severity was calculated (Wheeler, 1969) as [(Sum of all numerical ratings/ total number of main stems observed $\times$ maximum disease rating) $\times 100$ ].

\section{MANAGEMENT OF SCLEROTINIA ROT}

Rapeseed-mustard are repeatedly exposed to a number of pathogens and, as a result, they have evolved intricate defense mechanisms to recognize and defend themselves against a wide array of these pathogens by structural defense (Meena et al., 2010) and by including a set of defense responses that can defeat the invading pathogens (Vishwanath et al., 1999).

\section{SEARCH FOR RESISTANT GENOTYPES}

Host resistance offers the only economic and sustainable method for effective management of this disease (Zhao et al., 2004). Due to severe losses caused by the Sclerotinia rot in rapeseed-mustard, the objective of oilseed breeders is the development of resistant lines against Sclerotinia rot. Several attempts have been made in past to find out the sources of resistance against Sclerotinia rot, but no complete resistance to $S$. sclerotiorum is lacking in all cultivated rapeseedmustard crops, however, partial resistance was identified in some of the B. napus and to a lesser extent in $B$. juncea genotypes from China, Australia ( $\mathrm{Li}$ et al., 2008) and India (Singh et al., 2008 and Singh et al., 2010). B. napus and B. juncea cv. rugosa genotypes have been reported to possess resistance against Sclerotinia rot in the field as well as in green house conditions (Singh et al., 1994). Nine genotypes viz., Cutton, ZYR 6, PSM 169, PDM 169, Wester, PYM 7, Parkland, Tobin and Candle also showed resistance to Sclerotinia rot (Shivpuri et al., 1997). Pathak et al. (2002) reported that four genotypes viz., PCR-10, RW-8410, RW-9401 and RGN-8006 consistently proved promising against Sclerotinia stem rot of mustard. To date, complete resistance to the pathogen has not been identified, although partial resistance was reported in $B$. napus cv. Zhongyou 827 (Buchwaldt et al., 2003). A diverse range of 91 accessions of Brassica species of Australian, Chinese and Indian origin were tested against Sclerotinia rot at seedling stage under screen house conditions by Singh et al. (2008). The genotypes of B. juncea namely, JO 009, JN 031 and JN 033 of Australian origin were observed tolerant whereas, none of the Indian and Chinese lines was tolerant. However, in B. napus genotypes AG outback, Rainbow, RQ 011 and RQ 011-02M2 of Australian origin, Neelam and GSL 1 of Indian origin and YU 178 of Chinese origin were tolerant. Sharma et al. (2009) also reported that the genotypes of $B$. juncea namely EC 597328 (Montara), EC 597329 (Berry) and EC 597331 (Ringot I) of Chinese origin were tolerant, whereas none of the Indian lines was tolerant while, among B. napus genotypes EC 597258 (BLN 3343) of Australian origin was observed tolerant. Ninety eight genotypes (29 B. napus, 69 B. juncea) were also tested in the field conditions by Singh et al., (2010) and found that the genotypes of $B$. juncea including RH 13, Ringot $1, B$. juncea I, B. juncea II from China and JM 018 from Australia showed resistance to $S$. sclerotiorum. Goyal et al., (2011) screened 70 genotypes under field conditions and found that Ringot 1 showed resistance, Brassica I and Brassica II showed moderately resistance, while Haoyou II, Jinshanhung, JM 6009, JM 6010, JM 6011, JM 6012, JM 6018 showed moderately susceptible reaction and Montara, Amora, RL, JM 6026, JM 6004 and JM 6014 showed susceptible reaction. Recently, Rakesh (2014), identified fourteen genotypes viz., Varuna albino, RAUD 25, BIOYSR, PHR 2, Purple mutant, Montara, Ringot 1, Brassica I , Brassica II, EC 126743, EC 126745, EC 322090, EC 322091, Kiran showed moderately resistant reaction (10-20\% D.I) against stem rot disease.

\section{USE OF FUNGICIDES}

The explosive pathogenicity of $S$. sclerotiorum under favourable conditions and the ability of its sclerotia to withstand adverse conditions allow it to be a successful pathogen. Control of this disease by the use of different fungicides with varying degree of success has been reported in the literature (Mehta et al., 2005) but no economical and practical solution through the use of fungicides has been made so far. Moreover, chemical sprays in mustard is not feasible and economical as this disease appears late at pod formation stage to maturity in Haryana conditions (Rathi and Singh, 2009). However, significant control of disease through prophylactic sprays with systemic fungicides has been reported under field conditions (Rathi et al., 2012). Although efficacy of various fungicides against Sclerotinia species has been well demonstrated (Rowe 1982; Brenneman et al., 1987), it has not been controlled consistently and economically due to prolonged viability and unpredictable nature of fungal propagules (Singh and Kapoor 1993). Shivpuri et al. (2001) observed that fungicides, carbendazim, thiophenate methyl and phenylpyrrole had completely inhibited the growth of the pathogen at all the concentrations tested in vitro. Mancozeb was found effective at higher concentration while, copper oxychloride was least effective as it did not cause substantial reduction in growth of the pathogen and Antracol was mildly effective ex- 
hibiting mean growth of $40.6 \mathrm{~mm}$ as against $88.3 \mathrm{~mm}$ in check. Sharma et al., 2006 observed that captan completely inhibited mycelia growth with $\mathrm{EC}_{50}$ value less than $1 \mu \mathrm{g}$ a.i. $\mathrm{ml}^{-1}$. Seed treatment with carbendazim and foliar spray of the same at 65 days after sowing (DAS) proved most effective in reducing disease incidence $(91 \%)$, intensity $(98 \%)$ and increasing seed yield (91\%) over untreated check. Seed treatment with carbendazim alone $(0.1 \%)$ without any type of spray provided 56 per cent reduction in disease incidence (Ghasolia and Shivpuri, 2008). Both myceliogenic and carpogenic infections were obsreved minimum in carbendazim treatment (Sharma et al., 2011). Use of carbendazim and captan as foliar sprays has been reported to be very effective against Sclerotinia rot of pea (Sharma, 1987), rape (Shen, 1993). Benomyl, carbendazim and mancozeb@0.2\% controlled $S$. sclerotiorum on mustard and reduced the disease by 91.3, 85.7 and 54.7 per cent, respectively (Singh et al., 1994). Sasirekhamani et al., (2013) reported that the hexaconazole exerted an excellent fungistatic effect at $100 \mu \mathrm{g} / \mathrm{mL}$ concentration on $S$. sclerotiorum. Therefore, this fungicide could be effectively used for the control of the notorious pathogen, $S$. sclerotiorum at a time when many pathogens are acquiring resistance to different classes of fungicides. The prophylactic foliar spray with carbendazim @ $0.1 \%$ twice at 45 and 60 DAS was most effective in controlling Sclerotinia stem rot disease in Indian-mustard (Rathi et al., 2012; Rakesh et al., 2016).

\section{BIOLOGICAL CONTROL}

Biological control is a promising method of control of Sclerotinia rot diseases (Bardin and Huang, 2001). The first direct application of bio-control antagonists to control plant pathogens was made by Hartley (1921) inoculating soil with 13 antagonistic fungi in an attempt to control damping off of pine seedlings (Cook and Baker, 1983).

\section{BIO-CONTROL MECHANISMS ANTAGONISTS}

S. sclerotiorum being a destructive pathogen, it over winters as sclerotia in the soil or on the plant debris. Soil microbial community plays a vital role in reducing the inoculum build up of the pathogen. Among the microbes, both fungi and bacteria play a crucial role in degrading the sclerotial bodies. Activity of microbes is in its peak near the soil surface. Diurnal fluctuation of soil temperature, moisture and relative humidity lead to the development of cracks on the sclerotial rinds. It results in leakage of cell constituents and gets parasitized by the antagonistic microbes dwelling in the soil. The mycoparasitic fungi and bacteria associated with parasitized sclerotia include Coniothyrium minitans, Trichoderma spp., Gliocladium spp., Sporidesmium sclerotivorum, Fusarium, Hormodendrum, Mucor, Penicillium, Aspergillus, Stachybotrys and Verticillium
(Adam et al., 1979; Bedi, 1963; Makkonen and Pahjakallio, 1960). Among them, C. minitans and Gliocladium virens have shown practical potential for biological control of $S$. sclerotiorum (Budge et al., 1995).

\section{FUNGAL ANTAGONISTS}

C. minitans occurs naturally in soil as a mycoparasite of S. sclerotiorum. It was involved in the decline of viable sclerotia of $S$. sclerotiorum during crop growth and thereby suppresses the ascospores release (Whipps and Gerlagh, 1992; Sandy-winsch et al., 1993). C. minitans was first isolated from sclerotia of S. sclerotiorum in 1947. It was found to be associated with different soils and on several sclerotia forming fungi (Whipps and Gerlagh, 1992; Sandy-winsch et al., 1993). It parasitizes sclerotia, destroys it and reduces airborne ascospore infections. Soil application of $C$. minitans to different host crops reduced the sclerotial viability by destroying the propagation units (McLaren et al., 1996). C. minitans is also effective under a wide range of temperature and soil humidity (Hedke and Tiedemann, 1998). In general, the use of bio-control agents is restricted to controlled environments because they need stable environmental conditions for successful establishment in the infection court so as to prevent the infection of the pathogen (Whipps, 1994). However, it suggests the scope for using $C$. minitans for field-grown crops (McLaren et al., 1996; McQuilken et al., 1995). Soil application of $C$. minitans as mycoparasite was effective in reducing the incidence of Sclerotinia wilt in sunflower by parasitizing the sclerotia produced in the soil and in the plant system (Huang, 1980). However, C. minitans was successful in parasitizing the sclerotial bodies, it was unable to prevent the Eco-friendly methods in combating S. sclerotiorum (Lib.) de Bary, secondary spread of the actively growing mycelium (Huang, 1980). The carpogenic germination of sclerotial bodies of $S$. sclerotiorum was reduced by the mycoparasites $C$. minitans and Talaromyces flavus (Huang and Erickson, 2000). However, T. flavus suppressed the carpogenic germination of the sclerotia, it was inferior to $C$. minitans. Combined application of both $T$. flavus and $C$. minitans was not found to exert any synergistic or additive effect in the suppression of sunflower wilt (McLaren et al., 1996). Consecutive application of fungal antagonist is a pre-requisite to suppress the establishment of pathogen in the infection court. Soil application of either the above two antagonists continuously for two years suppressed sunflower wilt up to three years. But the crop raised during the subsequent year without the application of antagonist resulted in being susceptible (McLaren et al., 1996). Continuous monoculture of sunflower increased the natural population of $C$. minitans and Trichoderma spp., which in turn reduced the severity of sunflower wilt under field conditions (Huang and Kozub, 1991). 
The build up of antagonistic fungal flora during monoculture would increase the degradation of the sclerotia and thereby reduce the inoculum potential of the pathogen. In general, irrespective of the host, disease severity of Sclerotinia increases only during bloom stage. Hence, protection of the petals of the susceptible crops by pre-colonization of the senescing petals with antagonist will favour the multiplication of antagonists and thereby could prevent the establishment of ascospores on the infection court. Spraying spore suspension of $C$. minitans performed better in suppressing the white mold of dry bean (Huang and Kokko, 1993). However, C. minitans performed better in controlling $S$. sclerotiorum, its performance was found to decline when the environmental conditions favour disease development (Boland, 1989) and its consistency was not stable compared to the application of benomyl under field conditions (Huang et al., 2000). Treatment of sunflower seeds infected with $S$. sclerotiorum with conidia of $C$. minitans through film coating completely suppressed apothecial production of sclerotia and killed sclerotial bodies (McQuilken and Whipps, 2001). The research on C. minitans (Vrije et al., 2001) has led to the development of a commercial biopesticide named "Contans". Application of "Contans" recorded 60 per cent disease suppression on oilseed rape in a two year trial, but their experimental design was based on macro plots surrounded by guard areas to prevent major influences of invading external ascopores (Hedke et al., 1999). Davies, (1986) found that the presence of only a few apothecia in the field might still result in relatively high disease incidence levels. Instead the antibiotic producer Epicoccum purpurescens was not influenced by the change in environment. Foliar application of spore suspension of E. purpurascen effectively controlled white mold of bean (Huang et al., 2000). The disease suppression was due to the effective saprophytic colonization of petals by the antagonistic fungi. Soil incorporation of sclerotial parasite Sporidesmium sclerotivorum was effective up to five years in controlling Sclerotinia stem rot of soybean, a major problem in USA (Martinson and del Rio, 2001).

\section{BACTERIAL ANTAGONISTS}

Our planet is enriched with biodiversity, especially of prokaryotes. Bacterial antagonists like plant growth promoting rhizobacteria are exploited for the management of both foliar and soil borne pathogens of various economically important crop plants. Several bacterial antagonists such as Bacillus, Pseudomonas and Agrobacterium species are commercialized, for their potential role in disease management. But, research on the use of bacterial antagonists for the management of Sclerotinia rot fungus still remains to be explored and poorly studied. Strains of Bacillus spp. were frequently isolated Eco-friendly methods in combating Sclerotinia sclerotiorum (Lib.) de Bary from the sclerotia of S. sclerotiorum from North Dakota in the USA. Itadversely reduced the germination of infected sclerotia. Examination of infected sclerotia revealed that the integrity and colour of medulla was adversely affected (Wu, 1988). Spraying of B. cereus strain alf$87 \mathrm{~A}$ reduced the incidence of basal pod rot of pea caused by ascospore infection of $S$. sclerotiorum (Huang et al., 1993). Fifty three per cent of sclerotial bodies of $S$. sclerotiorum recovered from the soils of North Dakota were infected by Bacillus species. It increased degradation and reduced germination of the sclerotia (Nelson et al., 2001). Antagonistic Pseudomonas spp. (DF41) and P. chlororaphis (PA23) inhibited the germination of ascospores of $S$. sclerotiorum causal agent of stem rot of canola (Savchuk and Fernando, 2004). Delivering of DF41 and PA23 on to petals increased bacterial population after $24 \mathrm{~h}$ and later decreased between 96 and $120 \mathrm{~h}$ after application. Significant differences in disease severity were found with respect to timing of ascospore applications in the control treatments (ascospores only).One isolate completely suppressed disease when co-applied with ascospores, while only minor suppression occurred when applied 24 or $48 \mathrm{~h}$ after. Results from all studies indicated that PA23 and DF-41 are effective bio-control agents against $S$. sclerotiorum of canola (Savchuk and Fernando, 2004). A four-year study has shown that PA23and DF41 have a wide scope for the management of canola stem rot under field conditions (Savchuk, 2002; Zhang, 2004). Pantoea agglomerans isolated from leaves and flowers of canola produce oxalate oxidase and degrade oxalic acid produced by S. sclerotiorum, the pathogencity factor required for the successful establishment of the host-parasite relationship (Savchuk and Fernando, 2004).

\section{FUTURE WORK STRATEGY}

The following issues need to be addressed for Sclerotinia rot in rapeseed mustard:

Gene expression in Sclerotinia rot pathogens and host during infection of susceptible, tolerant and resistant varieties.

Search of resistant and moderately resistance sources against Sclerotinia rot in oilseed brassicas and wild relatives.

Search for alternative control methods of Sclerotinia rot of rapeseed-mustard.

Induced resistance and systemically acquired resistance (SAR).

Best use of IPM and IDM technology.

Coordination/cooperation/interaction with other researcher including plant breeders, statistician, soil scientist and institutions.

\section{Conclusion}

There is no doubt that Sclerotinia rot is the most destructive disease of rapeseed-mustard across the world. 
Sclerotinia rot causes considerable reduction in the quality and quantity of harvested product of rapeseedmustard and no proven source of resistance has been identified among cultivated oilseed brassica crop species. Due to lack of resistance in cultivated Brassicas against Sclerotinia rot, other methods could be used for management of this disease. One the most commonly used methods is the use of fungicides. In spite of tremendous use of fungicides against pathogens, theses fungicides cause serious health hazards to human beings and also they cause environmental pollution. Hence, at the present time more emphasis is made on other methods of disease management like growing moderately resistant varieties, use of plant and natural products, bio-control agents and alteration in agronomic practices because they are more economical, eco-friendly and safe.

\section{REFERENCES}

Adams, P.B. and Ayers, W.A. (1979). Ecology of Sclerotinia species. Phytopath, 69: 896-898

Anonymous (2015). Directorate of rapeseed-mustard research, www. drmr.res.in

Bandopadhyay, L., Basu, D. and Sikdar, S.R. (2013). Identification of genes involved in wild crucifer Rorippa indica resistance response on mustard aphid Lipaphis erysimi challenge, PL o S One, 8: 73632

Bardin, S.D. and Huang, H.C. (2001). Research on biology and control of Sclerotinia diseases in Canada. Canadian J. Pl. Pathol, 23: 88-98

Bedi, K.S. (1963). Some chemical and biological factors affecting the formation of apothecia of Sclerotinia sclerotiorum. Indian J. Bot. Sci., 42: 66-73

Bell, A.A. and Wheeler, M.H. (1986). Biosynthesis and functions of fungal melanins. Ann. Rev. Phytopathol, 24: 411-451

Ben-Yephet, Y., Genizi, A. and Siti, E. (1993). Sclerotial survival and apothetial production by Sclerotinia sclerotiorum following outbreak of lettuce drop. Phytopath, 83(5): 509-513

Boland, G. and Hall, R. (1994). Intensity of plant hosts of Sclerotinia sclerotiorum. Canadian J. Pl. Pathol, 2: 93108

Boland, G.J. (1989). Antagonism of white mold (Sclerotinia sclerotiorum) of bean by fungi from bean and rapeseed flowers. Canadian J. Bot., 67: 1775-1781

Bolton, M.D., Thomma, B.P.H.J. and Nelson, B.D. (2006). Sclerotinia sclerotiorum (Lib.) de Bary: Biology and molecular traits of a cosmopolitan pathogen. Mol. Pl. Pathol., 7: 1-16

Brenneman, T.B., Phipps, P.M. and Stipes, R.J. (1987). Survival of sclerotinia blight of peanut: Sensitivity and resistance of Sclerotinia minor to vinclozolin, iprodione, dicloran and PCNB. Pl. Dis, 71: 87-90

Buchwaldt, L., Yu, F.Q., Rimmer, S.R. and Hegedus, D.D. (2003). Resistance to Sclerotinia sclerotiorum in a Chinease Brassica napus cultivar. In: International Congress of PlantPathology, Chirstchurch, New Zealand, 27 February.

Budge, S.P., McQuilken, M.P., Fenlon, J.S. and Whipps, J.M. (1995). Use of Coniothyrium minitans and Gliocla- dium virens for biological control of Sclerotinia sclerotiorum in glass-house. Bio. Cont., 5: 513-522

Chaudhary, B.N. (1993). Yield loss estimation by Sclerotinia sclerotiorum (Lib.) de Bary. J. Ins. Agri. Animal Sci., 14: 113

Chauhan, L.S., Singh, J. and Chandra, D.R. (1992). Assessment of losses due to stem rot to yellow sarson. In: Proc. of national symposium on management of microbes in service of mankind. Nov. 19-21 at University of Allahabad, Allahabad, p. 65-66

Christias, C. and Lockwood, J.L. (1973). Conservation of mycelia constituents in four sclerotium forming fungi in nutrient deprived conditions. Phytopath, 63: 602-605

Clarkson, J.P., Staveley, J., Phelps, K., Young, C.S. and Whipps, J.M. (2003). Ascospore release and survival in Sclerotinia sclerotiorum. Myco. Res., 107: 213-222

Coley-Smith, J.R. and Cooke, R.C. (1971). Survival and germination of fungal sclerotia. Ann. Rev. Phytopathol., 9: 65-92

Cook, R.J. and Baker, K.F. (1983). Approaches to biological control. In: The natural and practice of biological control of plant pathogens. St. Paul, Minnesota, U.S.A.: The Ameri. Phytopathol. Soci., pp. 84-131

Cosic, J., Jurkovic, D., Vrandecic, K. and Kaucic, D. (2014). Survival of buried Sclerotinia sclerotiorum sclerotia in undisturbed soil. Helia, $35: 73-78$

Crisan, A. and Urlea, M. (1979). Influence of some geothermal waters on germination of the sclerotia and formation of apothecia of Sclerotinia sclerotiorum (Lib.) de Bary. St. Uni. Babes-Bolyai Biol., 24: 18-20

Davies, J. (1986). Diseases of oilseed rape. In D.H. Scarisbrick and R.W. Daniels' Oilseed rape. Mackays of Chantham, Great Britain, pp. 195-236

del Rio, L.E., Bradley, C.A., Henson, R.A., Endres, G.J., Hanson, B.K., McKay, K., Halvorson, M., Porter, P.M., Le Gare, D.G. and Lamey, H.A. (2007). Impact of Sclerotinia stem rot on yield of canola. Pl. Dis., 91: 191-194

Dillard, H.R., Ludwig, J.W. and Hunter, J.E. (1995). Conditioning sclerotia of Sclerotinia sclerotiorum for carpogenic germination. Pl. Dis., 79: 411-415

Dillion Weston, W.A.R., Loveless, A.R. and Taylor, R.E. (1946). Clover rot. J. Agri. Sci., 38: 18-28

Duncan, R.W., Dilantha Fernando, W.G. and Rashid, K.Y. (2006). Time and burial depth influencing the viability and bacterial colonization of sclerotia of Sclerotinia sclerotiorum. Soil Bio. Bioche., 38(2): 275-284

Favaron, F., Alighisi, P., Marciano, P. and Magro, P. (1988). Poly-galacturonase isoenzymes and oxalic acid produced by Sclerotinia sclerotiorum in soybean hypocotyls as elicitors of glyceollin. Physi. Mol. Pl. Patho., 35: 385-395

Ghasolia, R.P. and Shivpuri, A. (2005). Studies on carpogenic germination of sclerotia of Sclerotinia sclerotiorum (Lib.) de Bary, casuing Sclerotinia rot of Indian mustard. Indian Phytopathol, 58: 224-227

Ghasolia, R.P. and Shivpuri, A. (2008). Management of Sclerotinia rot of Indian mustard with plant extracts and fungicides. J. Myco. Pl. Patho., 38(2): 400-402

Ghasolia, R.P. and Shivpuri, A. (2009). Inoculum-disease relationships in Sclerotinia rot of Indian mustard (Brassica juncea). Indian Phytopathol, 62: 199-203

Ghasolia, R.P., Shivpuri, A. and Bhargava, A.K. (2004). Sclerotinia rot of Indian mustard (Brassica juncea) in 
Rajasthan. Indian Phytopathol, 57: 76-79

Goyal, P., Chahar, M., Barbetti, M., Liu, S.Y. and Chattopadhyay, C. (2011). Resistance to sclerotinia rot caused by Sclerotinia sclerotiorum in Brassica juncea and B. napus germplasm. Indian J. Pl. Prot., 39: 60-64

Grogan, R.G. (1979). Sclerotinia species: summary and comments on needed research. Phytopathol, 69: 908-910

Gurjar, R.B.S., Bansal, R.K. and Gupta, R.B.L. (2004). Viability of sclerotia of Sclerotium rolfsii at different depth and duration in soil of North -West India. J. Mycol. Pl. Pathol., 34(2): 558-559

Hammerschmidt, R., Nuckles, E.M., Kuc, J. (1982). Association of enhanced peroxidise activity with induced systemic resistance of cucumber to Colletotrichum lagenarium. Physiol. Pl. Patho., 20: 73-82

Hartley, C. (1921). Damping-off in forest nurseries. US Dept. Agric. Bull., 934: 1-99

Harvey, I.C., Foley, L.M. and Saville, D.J. (1994). Survival and germination of shallow-buried sclerotia of Sclerotinia sclerotiorum in pasture in canterbury. New Zealand J. Agri. Res., 38: 279-284

Hedke, K. and Tiedemann, A.V. (1998). Environmental influences on the decomposition of sclerotia of Sclerotinia sclerotiorum byConiothyrium minitans. Mitteil. Aus. Der. Biol. Bund, 357: 352

Hedke, K., Luth, P. and Tiedemann, A.V. (1999). Contans first biocontrol agent against Sclerotinia sclerotiorum in oilseed rape. In: The Proceedings of the $10^{\text {th }}$ International Rapeseed Congress. 26-29 September 2001. Canberra, Australia.

Henson, J.M., Butler, M.J. and Day, A.W. (1999). The dark side of mycelium: Melanins of phytopathogenic fungi. Ann. Rev. Phytopathol., 37: 447-471

Hieu, N.T. (2007). Integrated management of sclerotinia rot (Sclerotinia sclerotiorum (Lib.) de Bary) of Indian mustard (Brassica juncea L. Czern \& Coss.). M. Sc. Thesis, Chaudhary Charan Singh Haryana Agricultural University, Hisar, Haryana, p. 109.

Holley, R.C. and Nelson, B. (1983). Sclerotinia wilt of sunflower: Effect of inoculums density on disease incidence. Phytopathol., 73: 812

Horning, H. (1983). Zur epidemilogy und Bekafungder Weibstengelikeit (Sclerotinia sclerotiorum). Raps 1, p. 32-34

Huang, H.C. and Kozub, G.C. (1991). Temperature requirements for carpogenic germination of sclerotia of Sclerotinia sclerotiorum isolates of different geographic origin. Bot. Bull. Academia Sin. (Taipei), 32: 279-286

Huang, H.C. (1980). Control of Sclerotinia wilt of sunflower by hyperparasites. Canadian J. Pl. Pathol., 2: 26-32

Huang, H.C. and Erickson, R.S. (2000). Bio-control of apothecial production of Sclerotinia sclerotiorum in pulse and oilseed crops. Annu. Rep. Bean. Improv. Coop, 43: 90-91

Huang, H.C. and Kokko, E.G. (1993). Trichothecium roseum, a mycoparasite of Sclerotinia sclerotiorum. Canadian J. Bot., 71: 1631-1638

Huang, H.C. and Konzub, G.C. (1991). Temperature requirements for carpogenic germination of sclerotia of Sclerotinia sclerotiorum isolates of different geographic origin. Bot. Bull. Academia Sin., 32: 279-286

Huang, H.C., Bremer, E., Hynes, R.K. and Erickson, R.S. (2000). Foliar application of fungal biocontrol agent for the control of white mold of dry bean caused by Sclerotinia sclerotiorum. Bio. Cont., 18: 270-276

Huang, H.C., Kokko, E.G., Yanke, I.J. and Phillippe, R.C. (1993). Bacterial suppression of basal pod rot and end rot of dry peas caused by Sclerotinia sclerotiorum. $\mathrm{Ca}$ nadian J. Micro., 39: 227-233

Kang, I.S. and Chahal, S.S. (2000). Prevalence and incidence of white rot of rapeseed and mustard incited by Sclerotinia sclerotiorum in Punjab. Pl. Dis. Res., 15: 232233

Kapoor, K.S., Gill, H.S. and Sharma, S.R. (1987). Survival and carpogenic germination of sclerotia of Sclerotinia sclerotiorum. Indian Phytopathol., 40: 500-502

Kirk, P.M., Cannon, P.F., David, J.C. and Staipers, J.A. (2001). Ainsworth and Bisby's Dictionary of the Fungi, $9^{\text {th }}$ Ed. CABI Publicing, Wallingford, p.1-655

Kirkegaard, J.A., Robertson, M.J., Hamblin, P. and Sprague, S.J. (2006). Effect of blackleg and Sclerotinia stem rot on canola yield in the high rainfall zone of southern New South Wales, Australia. Aus. J. Agri. Res., 57: 201 $-212$

Krishnia, S.K., Meena, P.D. and Chattopadhyay, C. (2000). Seed-yield and yield-attributes of Indian mustard affected by Sclerotinia rot. J. Myco. Pl. Pathol., 30: 265

Kruger, W. (1980). On the effect of calcium cyanamide on the development of apothecia of Whetzelinia sclerotiorum (Lib.) Korf and Dumont, the agent of stalk rot of rape. Rev. Pl. Pathol., 59: 5438

Kruger, W., Marguard, W.R. and Schoosser, E. (1981). Plant disease product quality. II. Influence of stem canker Sclerotinia sclerotiorum (Lib.) de Bary on the quality of rapeseed. Rev. Pl. Pathol., 60: 2949

Kumar, D., Maurya, N., Bharati, Y.K., Kumar, A., Kumar, K., Srivastava, K., Chand, G., Kushwaha, C., Singh, S.K., Mishra, R.K. and Kumar, A. (2014). Alternaria blight of oilseed Brassicas: A comprehensive review. African J. Micro. Res., 8: 2816-2829

Lamey, H.A. (2003). The status of Sclerotinia sclerotioum on canola in North America. In: "Proc. 2003 Sclerotinia Initiative Annual Metting”, Bloomington, MN.

Lesovoi, M.P., Parfenyuk A.I. and Kondrafyuk, O.K. (1987). A method of identifying and selecting sunflower resistant to pathogen of white and grey mould. Miko.Fitopathol, 21:273-278

Li, Z., Zhang, M., Wang, Y., Li, R. and Fernando, W.G.D. (2008). Mycelial compatibility group and pathogenicity variation Sclerotinia sclerotiorum populations in sunflower from China, Canada and England. J. Pl. Pathol., 7: $131-139$

Libert, M.A. (1837). Plante crytogamicae arduennae (Exsiccati) no. 326. Published by the author.

Lodha, B.C., Bhatanagar, M.K., Mathur, K., Doshi, A., Mathur, S., Bairwa, L.N., Sharma, D. and Trivedi, A. (1992). Plant pathological thoughts and news. no.6 (3) Deptt. of Plant Pathology, Rajasthan College of Agriculture, Udaipur (India).

Lumdsen, R.D. (1969). Sclerotinia sclerotiorum infection of bean and the production of cellulose. Phytopathol., 59: 653-657

Lumdsen, R.D. (1976). Pectolytic enzymes of Sclerotinia sclerotiorum and their location in infected bean. Canadian J. Bot., 54: 2630-2641

Maiti, S. and Sen, C. (1988). Effect of moisture and tempera- 
ture on the survival of sclerotia of Sclerotium rolfsii in soil. J. Phytopathol., 121(2): 175-180

Makkonen, R. and Pohjakallio, O. (1960). On the parasites attacking the sclerotia of some fungi pathogenic to higher plants and on the resistance of those sclerotia to their parasites. Act. Agri. Scand., 10: 105-126

Marciano, P., Di Lenna, P. and Magro, P. (1982). Polygalacturonase isoenzymes and oxalic acid produced by Sclerotinia sclerotiorumin vivo and in vitro. Physi. Pl. Pathol., 20: 201-212

Martinson, C.A. and del Rio, E.L. (2001). Prolonged control of Sclerotinia sclerotiorum with Sporidesmium sclerotivorum. In: The $\mathrm{XI}^{\text {th }}$ International Sclerotinia Workshop, Central Science Laboratory, York, UK, July 8-12, p.133.

McLaren, D.L., Huang, H.C. and Rimmer, S.R. (1996). Control of apothecial production of Sclerotinia sclerotiorum by Coniothyrium minitans and Talaromyces flavus. Pl. Dis., 80: 1373-1378

McQuilken, M.P. and Whipps, J.M. (2001). Biocontrol of Sclerotinia sclerotiorum by film-coating Coniothyrium minitans on to seed and sclerotia. In: The XI th International Sclerotinia Workshop, Central Science Laboratory, York, UK, July 8-12, p. 131

Mc Quilken, M.P., Mitchell, S.J., Budge, S.P., Whipps, J.M., Fenlon, J.S. and Archer, S.A. (1995). Effect of Coniothyrium minitans on sclerotial survival and apothecial production of Sclerotinia sclerotiorum in field-grown oilseed rape. Pl. Pathol., 44: 883-896

Meena, P.D., Awasthi, R.P., Chattopadhyay, C., Kolte, S.J. and Kumar, A. (2010). Alternaria blight: a chronic disease in rapeseed mustard. J. Oilseed Brassica, 1: 1-11

Meena, P.D., Rathi, A.S., Kumar, V. and Singh, D. (2014). Compendium of rapeseed-mustard diseases: Identification and Management. Directorate of Rapeseed-Mustard Research (ICAR), Bharatpur (Rajasthan), pp. 30.

Mehta N., Sangwan, M.S. and Saharan, G.S. (2005). Fungal diseases of rapessed-mustard. in: Diseases of Oilseed Crops. (Ed. Saharan, G.S., Naresh Mehta and M.S. Sangwan) Indus Publishing Co. New Delhi, India. p. 15 $-86$.

Mehta, N., Hieu, N.T. and Sangwan, M.S. (2009). Influence of soil types, frequency and quantity of irrigation on development of sclerotia of stem rot of mustard. $J . M y$ col. Pl. Pathol., 39(3): 506-510

Morall, R.A.A. and Ducck, J. (1982). Epidemiology of Sclerotinia stem rot of rapeseed in Saskatchewan. Canadian J. Pl. Pathol., 4: 161-168

Morrall, R.A.A. and Dueck, J. (1983). Sclerotinia stem rot of spring rapeseed in Western Canada. Proceedings of the $6^{\text {th }}$ International Rapeseed Conference, Paris (France): 957-952

Morrall, R.A.A., Duczek, I.J., Mc Kenzie, D.L. and Mc Gee, D.C. (1976). Some aspect of Sclerotinia sclerotiorum in Saskatchewan. 1970-75. Canadian Pl. Dis. Sur., 56: 56

Nelson, B.D., Christianson, T. and McClean, P. (2001). Effects of bacteria on sclerotia of Sclerotinia sclerotiorum. In: The XI ${ }^{\text {th }}$ International Sclerotinia Workshop, Central Science Laboratory, York, UK, July 8-12, p. 39.

Ngugi, H.K., Scherm, H. and Nesmith, D.S. (2002). Distribution of pseudosclerotia of Monilinia vacciniicorymbosi and risk of apothecial emergence following mechanical cultivation. Phytopathol., 92(8): 877-883
Pande, P.P., Rathi, A.S., Avtar, R. and Kumar, A. (2008). Viability of sclerotia of Sclerotinia trifoliorum Erikss at different depth and duration in soil. For. Res., 34(1): 44-48

Pathak, A.K., Godika, S., Jain, J.P. and Muralia, S. (2002). Screening of Brassica genotypes against stem rot disease of mustard caused by Sclerotinia sclerotiorum (Lib.) de Bary. J. Mycol. Pl. Pathol., 32(1): 111- 112

Pope, S.J., Varney, P.L. and Sweet, J.B. (1989). Susceptibility of cultivars of oilseed rape to Sclerotinia sclerotiorum and the effect of infection on yield. Production and protection of oilseed rape and other Brassica crops. Asp. App. Bio., 23: 451-456

Price, K. and Colhoun, J. (1975). Pathogenicity of isolates of Sclerotinia sclerotiorum (Lib.) de Bary to several hosts. Phytopathol. Zeit., 83: 232-238

Purdy, L.H. (1955). A broad concept of species Sclerotinia sclerotiorum based on variability. Phytopathol., 45: 421 $-427$

Purdy, L.H. (1979). Sclerotinia sclerotiorum: History, diseases and symptomatology, host range, geographic distribution and impact. Phytopathol., 69: 875-880

Rakesh, (2014). Studies on Sclerotinia stem rot of Indian mustard (Brassica juncea (L.) Czern \& Coss.) caused by Sclerotinia sclerotiorum (Lib.) de Bary. M.Sc. Thesis submitted to CCS, HAU, Hisar.

Rakesh, Rathi, A.S. and Singh, H. (2015). Viability of sclerotia of Sclerotinia sclerotiorum at different depths and durations in soil. J. Oilseeds res., 32: 148-151

Rakesh, Rathi, A.S., Kumar, A. and Singh, H. (2016). Evaluation of fungicides for the control of Sclerotinia stem rot of Indian mustard caused by Sclerotinia sclerotiorum (Lib.) de Bary. J. Appl. Nat. Sci., 8: 441-444

Rathi, A.S. and Singh, D. (2009). Integrated management of Alternaria blight and white rust in Indian mustard. Paper presented in $16^{\text {th }}$ Australian Research Assembly on Brassica held at Ballarat Mercure Hotel, Ballarat, Victoria, Australia from September 14-16, 2009. In: Conference proceedings, p. 51-54

Rathi, A.S., Sharma, S. and Singh, D. (2012). Efficacy of carbendazim as prophylactic control of Sclerotinia rot in Indian mustard. Paper presented in $1^{\text {st }}$ National Brassica Conference on "Production Barriers and Technological Options in Oilseed Brassica" held at CCS HAU, Hisar from March 02-03, 2012. Abstracts p. 130.

Rouxel, T., Sarniguet, A., Kollman, A. and Bousquew, J.F. (1989). Accumulation of a phytoalexin in Brassica spp. In relation to a hypersensitive reaction to Leptoshaeria maculans. Physi. Mol. Pl. Pathol., 34: 507-517

Rowe, R.C. (1982). Recent advances in fungicides for vegetable disease control. Pl. Dis., 66: 966

Sandys-Winsch, D.C., Whipps, J.M., Gerlagh, M. and Kruse, M. (1993). World distribution of the sclerotial mycooparasite Coniothyrium minitans. Myco. Res., 97: 11751178

Sasirekhamani, M., Ebenezer, P., Nirmal Nevedhana, K.B. and Vijayan, V. (2013). The consequences of inhibition of ergosterol biosynthesis in Sclerotinia sclerotiorum (Lib.) de Bary by hexaconazole. Int. J. Phar. Life Sci., 4 (4): 2595-2604

Savchuk, S. (2002). Evaluation of biological control of Sclerotinia sclerotiorum in canola (Brassica napus) in the laboratory, in the greenhouse and in the field. M.Sc.Thesis, University of Manitoba, MB. 
Savchuk, S. and Fernando, W.G.D. (2004). Effect of timing of application and population dynamics on the degree of biological control of Sclerotinia sclerotiorum by bacterial antagonists. FEMS Micro. Eco. 49: 379-388.

Saxena, V.C. and Rai, J.N. (1987). Survey of occurrence of white rot of crucifers caused by Sclerotinia sclerotiorum in Uttar Pradesh and Bihar. Indian J. Myco. Pl. Pathol., 17: 89-91

Sharma, A.K. (1987). Sclerotinia rot - A threat to the cultivation of pea in the U.P. Hills. Seeds and Farms, 11: 21 $-22$

Sharma, P., Kumar, A., Meena, P.D., Goyal, P., Salisbary, P., Gurung, A., Fu, T.D., Wang, Y.F., Barbetti, M.J. and Chattopadhyay, C. (2009). Search for resistance to Sclerotinia sclerotiorum in exotic and indigenous Brassica. Ballarat Victoria.

Sharma, P., Meena, P.D., Rai, P.K., Kumar, S. and Siddiqui, S.A. (2011). Evaluation of soil amendments, botanical and fungicides against Sclerotinia sclerotiorum causing stem rot of Indian mustard. J. Myco. Pl. Pathol., 41(1): 151

Sharma, P., Verma, P.R., Meena, P.D., Kumar, V. and Singh, D. (2015). Research progress analysis of Sclerotinia rot (Sclerotinia sclerotiorum) of Oiseed Brassicas through bibliography. J. Oilseed Brassica, 6: 45-125

Sharma, S.K., Arora, S.K. and Gandhi, S.K. (2001). Evaluation of Brassica species/ varieties for resistance against Sclerotinia sclerotiorum. In: Proc. Symposium on Current Trends in Teaching, Research and Extension in Plant Pathology, CCS HAU, Hisar, India, Dec., 12-13, 2001. p. 62.

Sharma, S.K., Arora, S.K. and Gandhi, S.K. (2006). Integrated management of Sclerotinia rot of Brassica juncea (L.) Czern and Coss. Pl. Dis. Res, 21(2): 132137

Shaw, F.J.W. and Ajrekar, S.L. (1915). The genus Rhizoctonia in Indian. Dept. Agri. Nom. Bot. Ser., 7: 177-194

Shekhawat, K., Rathore, S.S., Preml, O.P., Kandpal, B.K. and Chauhan, J.S. (2012). Advances in agronomic management of Indian mustard (Brassica juncea): An overview. J. Agron., 1-14.

Shen, W.Z. (1993). Control of Scleortinia rot of rape (Sclerotinia sclerotiorum de Bary) with $40 \%$ carbendazim. Pl. Prot., 18: 50

Shirashi, T., Yamaoka, N. and Kunch, H. (1989). Association between increased phenylalanine ammonia-lyase activity and cinnamic acid synthesis and the induction of temporary in accessibility caused by Erysiphe graminis primary germ tube penetration of the barley leaf. Physi. Mol. Pl. Pathol., 34: 75-85

Shivapuri, A., Bhargava, A.K. and Chippa, H.P. (2001). Sclerotinia sclerotiorum- a new threat to mustard cultivation in Rajasthan, In: Proceeding of Sclerotinia 2001, the XI International Sclerotinia Workshop (C.S. Young and K.J.D. Hughes. eds.). York 8-12, July, 2001, Central Science Laboratory, York, England, p. 177-178

Shivpuri, A., Chhipa, H.P., Gupta, R.B.L. and Sharma, K.N. (1997). Field evaluation of mustard genotypes against white rust, powdery mildew and stem rot. Annals Arid Zone, 36: 387-389.

Shivpuri, A., Sharma, K.B. and Chhipa, H.P. (2000). Some studies on the stem rot (Sclerotinia sclerotiorum) disease of rapeseed/mustard in Rajasthan. J. Myco. Pl.
Pathol. 30: 268.

Shukla, A.K. (2005). Estimation of yield losses to Indian mustard (Brassica juncea). J. Phytopathol. Res. 18: 267 -268 .

Singh, D. and Kapoor, A.S. (1993). Effect of fungicides on various growth stages of Sclerotinia sclerotiorum. $J$. Myco. Pl. Pathol., 26: 185-189

Singh, R., Singh, D. Salisbury, P. and Barbetti, M.J. (2010). Field evaluation of Indian and exotic Oilseed Brassica napus and B. juncea germplasm against Sclerotinia stem rot. Indian J. Agri. Sci., 80: 1067-1071

Singh, R., Singh, D., Barbetti, M.J., Singh, H., Caixia, L., Sivasithamparam, K., Salisbury, P., Burton, W. and Tingdong, F. (2008). Sclerotinia rot tolerance in oilseed Brassica. J. Oilseeds Res, 25: 223-225

Singh, R., Tripathi, N.N. and Kaushik, C.D. (1994). Management of Sclerotinia rot of Indian mustard (Brassica juncea (L.) Czern and Coss.) by fungicides. Crop Res. 7: $276-281$

Singh, R.S. (1998). Sclerotinia rots and wilts. In: Plant Diseases. $7^{\text {th }}$ edition, Oxford and IBH Publishing Co. Pvt. Ltd., New Delhi, p. 298-314

Singh, S. and Singh, H. (1988). Formation of apothecia by sclerotia of Sclerotinia trifoliorum Erikss-A new record in India. Curr. Sci., 57: 18

Smith, V.L., Jenkins, S.F., Punja, Z.K. and Benson, D.M. (1989). Survival of sclerotia of Sclerotium rolfsii influence of sclerotia treatment and depth of burial. Soil Bio. Bioche., 21(5): 627-632

Southerton, S.G. and Deverall, B.J. (1990). Changes in phenylalanine ammonia-lyase and peroxidise activities in wheat cultivars expressing resistance to the leaf rust fungus. Pl. Pathol., 39: 223-230

Subbarao, K.V., Koike, S.T. and Hubbard, J.C. (1996). Effect of deep plowing on the distribution and density of Sclerotinia minor sclerotia and lettuce drop incidence. Pl. Dis., 80(1): 28-33

Susan, J., Mitchell and Wheeler, B.E.J. (1990). Factor affecting the production of apothecia and longevity of sclerotia of Sclerotinia sclerotiorum. Pl. Pathol., 39: 70-76

Vishwanath, Kolte, S.J., Singh, M.P. and Awasthi, R.P. (1999). Induction of resistance in mustard (Brassica juncea) against Alternaria black spot with an avirulent Alternaria brassicae isolate. Eur. J. Pl. Pathol., 105: 217-220

Vrije, T.d., Antoine, N., Buitelaar, R.M., Bruckner, S., Dissevelt, M., Durand, A., Gerlagh, M., Jones, E.E., Luth, P., and Oostra, J. (2001). The fungal biocontrol agent Conithyrium minitans: production by soild-state fermentation, application and marketing. App. Micro. Biotech., 56: 58-68

Wakefield, E.N. (1924). On the names Sclerotinia sclerotiorum (Lib.) Massee, and S. libertiana Fuckel. Phytopathol., 14: 126-127

Wheeler, B.E.J. (1969). An Introduction to Plant Diseases. John Willey and Sons Ltd., London, p. 301.

Whipps, J.M. (1994). Advances in biological control in protected crops. Brighton Crop Protection Conference, Pests and Diseases 1994, p. 1259-1264.

Whipps, J.M. and Gerlagh, M. (1992). Biology of Coniothyium minitans and its potential for use in disease biocontrol. Mycol. Res., 96: 897-907

Willetts, H.J. and Wong, J.A.L. (1980). The biology of Scle- 
Rakesh et al. / J. Appl. \& Nat. Sci. 8 (4): 2325-2336 (2016)

rotinia sclerotiorum, S. trifoliorum, and S. minor with emphasis on specific nomenclature. Bot. Rev., 46: 101-165

$\mathrm{Wu}$, H. (1988). Effects of bacteria on germination and degradation of sclerotia of Sclerotinia sclerotiorum (Lib.) de Bary. M.Sc., Thesis, North Dakota State University, Fargo, ND.

Zhang, Y. (2004). Biocontrol of sclerotinia stem rot of canola by bacterial antagonists and study of biocontrol mechanisms involved. M.Sc.Thesis, University of Manitoba, MB.

Zhao, J., Peltier, A.J., Meng, J., Osborn, T.C. and Grau, C.R. (2004). Evaluation of Sclerotinia stem rot resistance in oilseed Brassica napus using a petiole inoculation technique under greenhouse conditions. Pl. Dis., 88: 10331039 